\title{
Protective effect of a novel antifungal peptide derived from human chromogranin a on the immunity of mice infected with Candida krusei
}

\author{
RUIFANG LI, LIN ZHANG, HUIRU ZHANG, YANJIE YI, LE WANG, LIANG CHEN and LAN ZHANG \\ College of Biological Engineering, Henan University of Technology, Zhengzhou, Henan 450001, P.R. China
}

Received September 9, 2016; Accepted March 9, 2017

DOI: $10.3892 / \mathrm{etm} .2017 .4290$

\begin{abstract}
Invasive fungal infections threat the life of immunocompromised patients. Chromogranin A N-46 (CGA-N46), corresponding to the 31st to 76th amino acids of the N-terminus of human chromogranin $\mathrm{A}$, is an antifungal peptide. In order to elucidate the antifungal effects of CGA-N46 in vivo, we studied its effects on cell-mediated immunity in Candida krusei-infected mice. The results showed that the treatment with CGA-N46 increased the average body weight and decreased the mortality of the immunocompromised mice model infected with Candida krusei. The spleen and thymus indices of treated mice has markedly increased compared with that of the control group $(\mathrm{P}<0.05)$, and the immune cell levels in peripheral blood also increased significantly $(\mathrm{P}<0.05)$. The immuno-modulatory effect of CGA-N46 (60 mg/kg/day) was found to be comparable to that of terbinafine. Additionally, CGA-N46 could alleviate or eliminate histopathological symptoms in the liver, spleen, kidney, and lung tissues. In conclusion, the present study suggests that CGA-N46 may offer a new strategy for antifungal therapeutic option. This study is an essential step in elucidating the effect of CGA-N46 in vivo.
\end{abstract}

\section{Introduction}

The incidence of invasive fungal infections (IFIs) has markedly increased in recent decades owing to increase in the

Correspondence to: Professor Ruifang Li, College of Biological Engineering, Henan University of Technology, 100 Lianhua Street, Zhengzhou, Henan 450001, P.R. China

E-mail: 1rf@haut.edu.cn

Abbreviations: CGA-N46, a derived peptide from N-terminus of human chromogranin A, corresponding to the 31st to 76th amino acid; CFU, colony-forming unit; H\&E, hematoxylin and eosin; IFIs, invasive fungal infections; mM, millimole per liter; SEM, standard error of the mean; WBC, white blood cell

Key words: chromogranin A, CGA-N46, antifungal peptide, immunocompromised Candida krusei-infected mice model, immuno-modulatory effect, protective effect number of immunocompromised patients $(1,2)$. Despite the development of new antifungal drugs, the mortality rate of IFIs remains high (2). Candida species remain a major cause of IFIs, resulting in significant morbidity and mortality in health care settings $(1,3,4)$. Moreover, the number of candidemia cases caused by non-albicans Candida species has been increasing in recent years (5-7). It is known that the treatment of some Candida species is difficult because of their innate or acquired resistance to antifungal agents (8-10). For instance, Candida krusei is intrinsically resistant to fluconazole $(1,11)$. Although its prevalence remains low among yeast infections (2-5\%), its intrinsic resistance to fluconazole is the reason C. krusei infections have the highest mortality rate (30-60\%) compared to other Candida species $(1,10,12)$.

Antimicrobial peptides (AMPs) are currently being studied extensively to assess their use as a new class of antimycotics because they possess broad-spectrum antimicrobial activities and may possibly thwart resistance (13-15). Chromogranin A is a major soluble protein of the adrenal medullary chromaffin granules and neurons, and is conservative in mammals $(16,17)$. Vasostatin-1, corresponding to the 1st to 76th amino acids of bovine chromogranin $\mathrm{A}$, is a natural antimicrobial peptide derived from the processing of bovine chromogranin A, and abundant naturally secrets (18). Research has demonstrated that the C-terminal moiety of bovine vasostatin-1 has potent antifungal activity. The disulfide bridge loop of $\mathrm{Cys}^{17}-\mathrm{Cys}^{38}$ in vasostatin-1 was crucial for its antibacterial activity but not necessary for its antifungal activity (19). To further explore the antifungal activity of the vasostatin-1 derived peptide and avoid aggregation, CGA-N46 which corresponded to human CGA residues 31-76 was synthesized. Our previous studies elucidated that CGA-N46 peptide had specific anti-Candidal activity, especially showed the highest antagonistic activity to C. krusei, without hemolytic activity on human erythrocytes in vitro (20). CGA-N46 inhibited the growth of Candida species by decreasing intracellular reactive oxygen species levels and mitochondria membrane potentials while also inhibiting DNA synthesis (21).

However, little is known about the in vivo activity of CGA-N46 in the treatment of candidiasis in immunocompromised hosts. In this study, candidemic mice was used to investigate the effects of CGA-N46 on immune cells and organ tissues with that of terbinafine was compared. 


\section{Materials and methods}

CGA-N46 preparation. CGA-N46 were synthesized by solid-phase peptide synthesis method. Peptide purification was performed using high-performance liquid chromatography (HPLC). The mass of the peptide was confirmed via mass spectrometry. Final purity of the peptides was determined to be $90 \%$ by analytical HPLC.

Experimental animals. Specific-pathogen-free female and male Kunming (KM) mice ( $\mathrm{n}=144)$, 4-weeks-old, weighing approximately 22-27 g, were purchased from the Laboratory Animal Center of Zhengzhou University, Zhengzhou, China. They were housed in an air-conditioned room maintained at $26^{\circ} \mathrm{C}$ with a $12 \mathrm{~h}$ light $/ 12 \mathrm{~h}$ dark cycle in filter-top cages and fed ad libitum a diet of laboratory chow and tap water (22).

Candida species are the pathogens of opportunistic mycosis. They are easy to infect immuno-compromised patients. Hereby, to get immuno-compromised animals, all mice received intraperitoneal injections of cyclophosphamide at a dose of $200 \mathrm{mg} / \mathrm{kg} / \mathrm{day}$ for 3 days after one week of adaptive feeding. The number of leukocytes was counted $24 \mathrm{~h}$ after cyclophosphamide administration. When the leukocyte count reached less than $1,000 / \mathrm{ml}$, suspension, containing $10^{5} \mathrm{CFU} / \mathrm{ml}$ fresh C. krusei in a $0.2 \mathrm{ml}$ volume of $0.9 \%$ sodium chloride $(\mathrm{NaCl})$, was slowly administered to each mouse via intraperitoneal injection. The inoculum concentration was confirmed by plating serial dilutions of the suspension onto SD agar medium plates.

Strain culture. Candida krusei API-600010 was supplied by the Department of Hematology, Peking University First Hospital, Beijing, China. The C. krusei culture was prepared using a method described by Petraitiene et al (23). with modest amendments. A loop of fresh C. krusei cells from fresh Sabouraud's (SD) agar slant was transferred into $10 \mathrm{ml}$ of fresh SD broth medium and centrifuged $\left(220 \mathrm{rpm}\right.$ at $30^{\circ} \mathrm{C}$ for $\left.12 \mathrm{~h}\right)$. The concentration of cells was adjusted using a hemocytometer, which was confirmed through a quantitative culture using a 10 -fold serial dilution. An inoculum of fresh C. krusei suspension $\left(10^{5} \mathrm{CFU} / \mathrm{ml}\right)$ in a $0.2 \mathrm{ml}$ volume of $0.9 \% \mathrm{NaCl}$ was administered slowly to each mouse via intraperitoneal injection. The inoculum concentration was confirmed by plating serial dilutions of the suspension onto Sabouraud's agar medium plates.

CGA-N46 administration. Administration of the compounds $(0.9 \% \mathrm{NaCl}, \mathrm{CGA}-\mathrm{N} 46$ and terbinafine) was initiated $24 \mathrm{~h}$ after inoculation of $C$. krusei. The mice were randomly divided into four groups: Control group, intraperitoneal injection of $200 \mu 10.9 \% \mathrm{NaCl}, \mathrm{n}=36 ; 30 \mathrm{mg} / \mathrm{kg} /$ day CGA-N46 group, intraperitoneal injection of CGA-N46 with concentration in the blood of mice was MIC against $C$. krusei $(0.1 \mathrm{mM}), \mathrm{n}=36$; $60 \mathrm{mg} / \mathrm{kg} /$ day CGA-N46 group with concentration in the blood of mice was 2-folds of MIC against $C$. krusei $(0.2 \mathrm{mM}), \mathrm{n}=36$; and terbinafine group, intraperitoneal injection of terbinafine $3.8 \mathrm{mg} / \mathrm{kg} / \mathrm{day}$ according to the usage of introduction, $\mathrm{n}=36$. All mice were injected one time each day and subjected to 2 weeks of injections.

The animals were monitored daily for mortality and body weight loss. They were humanely euthanized prior to the end of the experiments or when specific signs appeared (inability to reach food and water, lethargy or decreased mental alertness, labored breathing, inability to remain upright) and are not expected to survive until the next scheduled evaluation.

Sampling. After 3, 5, 7, 10, 12 and 14 days of treatment, mice from the control and treatment groups were euthanized by intraperitoneal injection of pentobarbital sodium $(60 \mathrm{mg} / \mathrm{kg})$. Fresh peripheral blood samples were collected to quantify blood cells. After euthanasia, the weights of the mice's thymuses and spleens at 5, 10, 12 and 14 days of treatment were measured. The thymus and spleen indices were calculated in the following manner: Organ index = organ weight $(\mathrm{mg}) /$ body weight $(\mathrm{g})$.

Triplicate samples were collected at each experiment.

Tissues from their livers, spleens, lungs, and kidneys were removed, and washed thoroughly with $0.9 \% \mathrm{NaCl}$ to remove residual blood. Afterwards, the tissue samples were cut into pieces $(5 \times 5 \mathrm{~mm})$ and fixed with $4 \%(\mathrm{v} / \mathrm{v})$ paraformaldehyde solution (24). The paraformaldehyde solution was replaced with fresh paraformaldehyde solution every $24 \mathrm{~h}$ and this was repeated thrice for tissue sample preparation.

Histopathological observation of tissue sections. Tissue sections were prepared according to the method developed by Ding (25) with a little modification. Briefly, the fixed tissue specimens were dehydrated and embedded in paraffin wax and then stored at $28^{\circ} \mathrm{C}$ for more than $12 \mathrm{~h}$. Next, we cut serial paraffin sections $(4 \mu \mathrm{m})$ and stored them at $65^{\circ} \mathrm{C}$ for more than $30 \mathrm{~min}$. The sections were immersed in xylol for three consecutive washes ( $5 \mathrm{~min}$ each) to remove paraffin. Then, the sections were hydrated with a series of alcohol washings of descending strength $(100,95,85,80$ and $70 \%)$, ending with de-ionized water. The histological paraffin sections were then stained with hematoxylin and eosin. Changes in organizational structure were visualized with an Olympus BX51 microscope set at $\mathrm{x} 100$ and $\mathrm{x} 400$ magnification.

Statistical analysis. Experimental data were analyzed using the SPSS 18.0 statistical program (SPSS, Inc., Chicago, IL, USA) to perform a one-way analysis of variance followed by the Duncan test. The results are reported as mean \pm standard error of the mean (SEM). Differences between each two groups were considered to be statistically significant at $\mathrm{P}<0.05$.

Ethics statement. All experimental procedures described in this work were performed in strict accordance with the guidelines suggested for the care and use of laboratory animals formulated by the Animal Ethics Committee of Zhengzhou University, which approved this protocol (Permit no. 2015-0002). All the injections were performed after animals were temporarily anesthetized with $1-5 \%$ isoflurane (administered by bell jar and maintained by nose cone). All the surgeries were performed under sodium pentobarbital anesthesia $(60 \mathrm{mg} / \mathrm{kg})$, and all efforts were made to minimize suffering.

\section{Results}

Effects of CGA-N46 on body weight and mortality. During the treatment period, the body weight of the survival mice and survival rate of each group were collected and recorded 
A

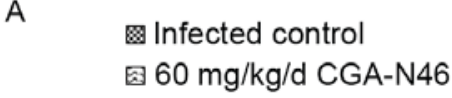

III $30 \mathrm{mg} / \mathrm{kg} / \mathrm{d}$ CGA-N46

Q Terbinafine

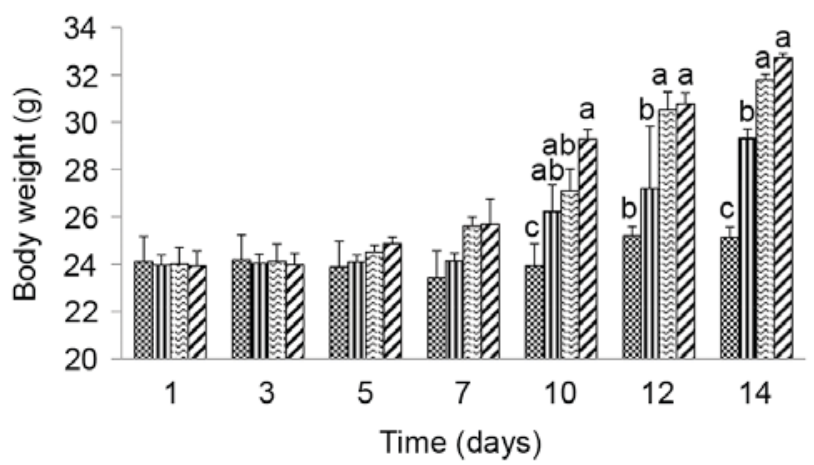

B

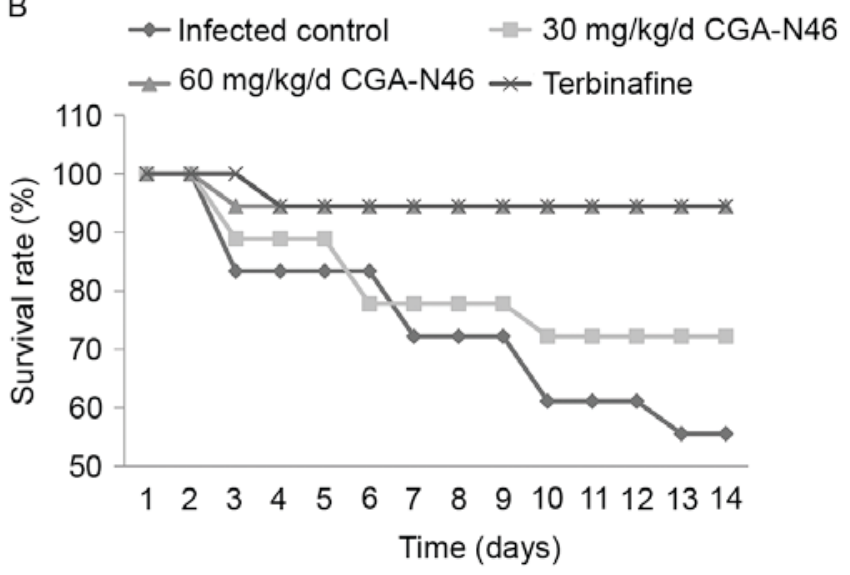

Figure 1. The average body weights of (A) the survival mice and (B) the survival rates of each tested group. Data were represented as mean \pm SEM. Differences between groups were considered to be statistically significant at $\mathrm{P}<0.05$ and shown as different letters. The different letter above the bar means significant difference between groups. The same letter above the bar means no significant differences.

A

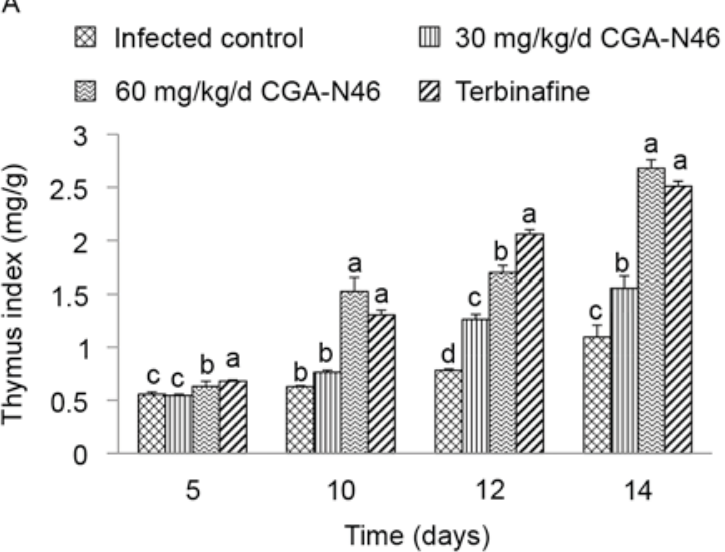

B

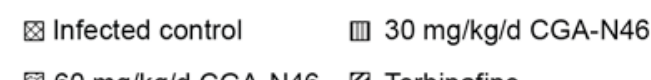

圆 $60 \mathrm{mg} / \mathrm{kg} / \mathrm{d}$ CGA-N46 $\square$ Terbinafine

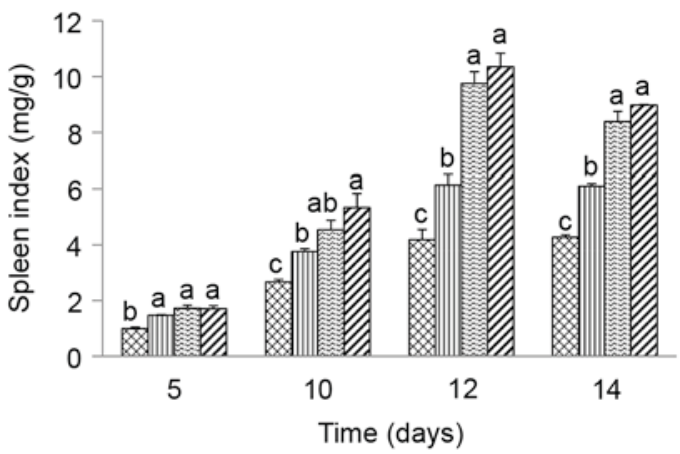

Figure 2. The effect of CGA-N46 on (A) thymus index and (B) spleens index. Differences between groups were considered to be statistically significant at $\mathrm{P}<0.05$ and shown as different letters. The different letter above the bar means significant difference between groups. The same letter above the bar means no significant differences.

(Fig. 1). Compared with the control group, the body weight of the survival mice increased more quickly after 10 days of treatment. At the 14th day of the experiment, the average body weight of the control group increased $1.083 \mathrm{~g}$, and the survival rate was $55.56 \%$. Meanwhile, the average body weight of the $60 \mathrm{mg} / \mathrm{kg} /$ day CGA-N46 group increased $7.77 \mathrm{~g}$, and the survival rate was $94.44 \%$. The effects of CGA-N46 on body weight and mortality of the infected mice were dose-dependent. The increase in body weight and the decline in mortality were not significantly different between the $60 \mathrm{mg} / \mathrm{kg} / \mathrm{day}$ CGA-N46 and terbinafine groups.

Effect of CGA-N46 on thymus and spleen indices. The effects of CGA-N46 on lymphatic organs at 5, 10, 12 and 14 days after treatment were studied and the thymus and spleen indices were recorded. As shown in Fig. 2, the thymus and spleen indices increased in a time-dependent manner. Also, compared to control, CGA-N46 significantly increased the thymus and spleen indices in a dose-dependent manner $(\mathrm{P}<0.05)$. Note that the effects of $60 \mathrm{mg} / \mathrm{kg} /$ day CGA-N46 on thymus and spleen indices were not significantly different from the effects of terbinafine.
Effect of CGA-N46 on immune cells. The level of white blood cells (WBCs) and lymphocytes, monocytes, neutrophil granulocytes in peripheral blood samples reflect the effects of CGA-N46 on mice immunity. The effects of CGA-N46 on immune cells were shown in Fig. 3. The immunosuppressant cyclophosphamide and Candida albican-infection could reduce the levels of WBCs. The levels of WBC, lymphocyte and monocyte in the control group were lower than the normal physiological level throughout the experiment. CGA-N46 could increase the levels of WBC, lymphocyte and monocyte in peripheral blood at a concentration-dependent and time-dependent manner. The immune cell levels of the CGA-N46 treated mice differed significantly from the control mice $(\mathrm{P}<0.05)$. It is puzzling that neutrophil granulocyte levels were lower in the treatment groups than in the control group which need to be further research.

Histopathological observation of tissues. The histopathology of the mice was examined at the indicated time points after CGA-N46 administration. The histopathological changes of the lungs, liver, spleen and kidneys on the 14th day of 

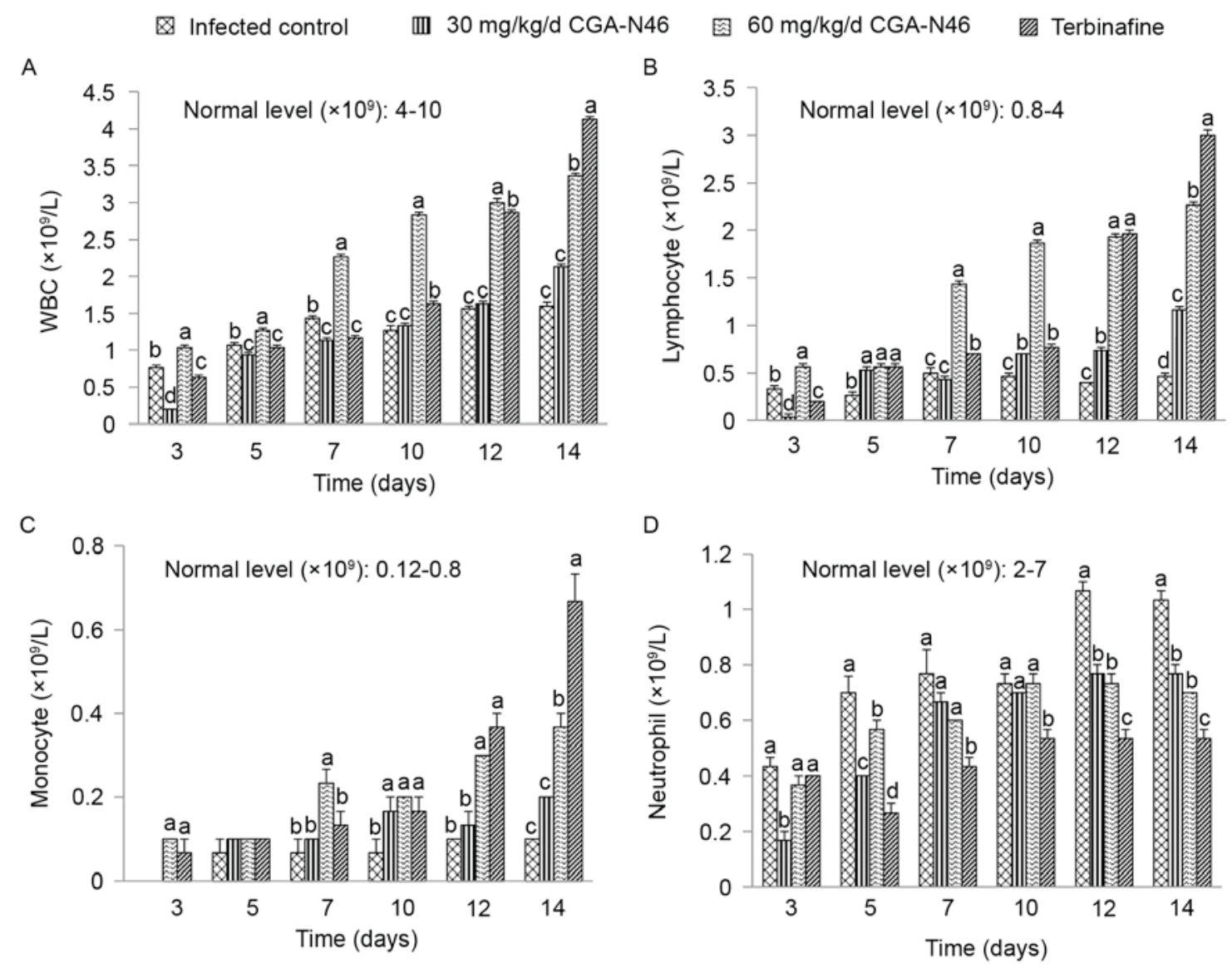

Figure 3. The effect of CGA-N46 on (A) white blood cells, (B) lymphocytes, (C) monocytes, and (D) neutrophil granulocytes. Differences between groups were considered to be statistically significant at $\mathrm{P}<0.05$ and shown as different letters. The different letter above the bar means significant difference between groups. The same letter above the bar means no significant differences.

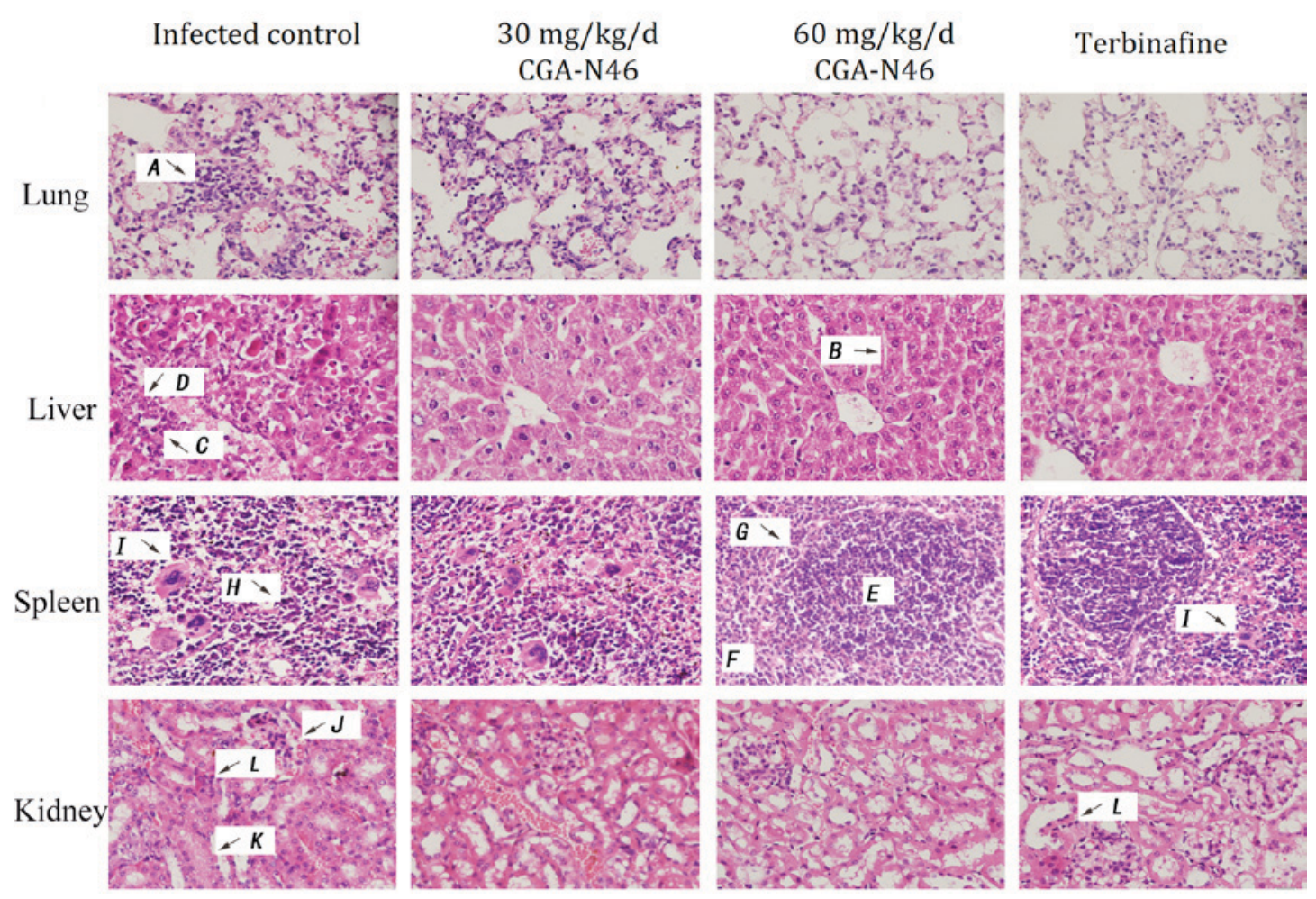

Figure 4. Histopathological changes of tissues on day 14 of CGA-N46 treatment. H\&E staining. $A$, alveolar interstitial lymphocytes infiltration; $B$, hepatic cord; $C$, nuclear pyknosis; $D$, nuclear dissolution; $E$, white pulp; $F$, red pulp; $G$, the boundaries between the red pulp and white pulp; $H$, structural disordered splenic corpuscles; $I$, macrophages; $J$, bleeding; $K$, swelling of the glomerulus; $L$, inflammatory cells. 
CGA-N46 treatment are shown in Fig. 4. The lesions in each tissue of the control group were more severe than those in the treatment groups.

In the control group, the lung lesions were characterized as severe alveolar interstitial lymphocytes infiltration. In liver section, no discernable normal lobular architecture and hepaticcord could be seen, and nuclear pyknosis or dissolution appeared. In the spleen, the boundaries between the red pulp and white pulp were unclear, and the structure was severely disordered. There were no visible splenic corpuscles or obvious germinal centers, and we observed a large number of macrophage cells scattered throughout the splenic parenchyma. In the kidney tissue sections, bleeding, swelling of the glomerulus, interstitial edema, and inflammatory cell infiltration were observed. While, CGA-N46 could mitigate the damage caused by $C$. krusei infections by reducing inflammatory cell infiltration and recovering tissues structure in a concentration- and time-dependent manner. At day $14,60 \mathrm{mg} / \mathrm{kg} /$ day treatment showed more effective than Terbinafine because, in Terbinifine treatment group, there were more macrophage cells in spleen tissue and more inflammatory cells in kidney tissue (Fig. 4).

\section{Discussion}

Candidiasis is the mycosis caused by the dimorphic fungus Candida spieces. In contrast to the other pathogenic fungi, C. albicans is a member of the normal microbiota within the gastrointestinal tract, respiratory tract, vaginal area, and mouth. In healthy individuals, $C$. albicans does not produce disease. Growth is suppressed by other microbiota (26). In recent decades, The incidence of fungal infections is growing worldwide with the increase of immuno-compromised patients $(1,27)$. Candida species are important reasons for different clinical manifestations, and they cause significant mortality and morbidity in health care settings $(1,4)$. Candida species are the pathogens of opportunistic mycosis. They are easy to infect immuno-compromised patients. Therefore, normal immunity is important for fungal infection. Hereby, the effect of CGA-N12 on the immunity of experimental animals was investigated in present study.

For effective establishment of C. krusei-infected mice, cyclophosphamide was administrated at the dosage of $200 \mathrm{mg} / \mathrm{kg} /$ day prior to the inoculation of C. krusei. The serum leukocyte levels were less than $1,000 / \mathrm{ml}$ after 3 days of administration. Thymus indices, spleen indices and leukocyte levels in peripheral blood sample of the control group indicated that the mice's immunity was damage. During the immunocompromised period, C. krusei could not induce an immune reaction in the infected mice. Compared to the control, CGA-N46 had immunomodulatory activities.

Thymus and spleen indices are the two important indicators of immunity. The indices are directly correlated to organ functionality and the number of immune cells. For that reason, they have been widely used to assess immunity responses (28). CGA-N46 could promote the immune activity of the thymus and spleen. The effect of CGA-N46 on thymus indices, spleen indices and immune cells was comparable to that of terbinafine, which is an effective antifungal drug. CGA-N46 was predicted to exert immuno-modulatory effect in the treatment of invasive candidiasis in immunocompromised mice, and the effects of CGA-N46 in vivo were dose-dependent.

Splenic macrophages have significantly greater antifungal activity against the pseudohyphae in the Candida spp. than that macrophage populations in the liver and lungs $(22,23,29)$. In the present study, more macrophages were observed in the spleen than that in the liver, kidneys, and lungs. Compared with the $60 \mathrm{mg} / \mathrm{kg} / \mathrm{day}$ CGA-N46 and terbinafine treatment groups, more macrophages were observed in the splenic tissue sections of the control group and the $30 \mathrm{mg} / \mathrm{kg} /$ day CGA-N46 treatment group. We predicted that more macrophages existing in the splenic tissue of the infected control samples and $30 \mathrm{mg} / \mathrm{kg} / \mathrm{day}$ CGA-N46 treatment samples may be caused by more C. krusei isolates in them. Compared the pictures of Terbinafine treatment group with $60 \mathrm{mg} / \mathrm{kg} /$ day CGA-N46 treatment group, macrophages were found in the splenic tissue of Terbinafine treatment group. The result indicated that CGA-N46 was more effective than Terbinafine.

\section{Acknowledgements}

This study was supported by the National Science Foundation of China (grand nos. 31071922 and 31572264 ), Project of science and technology of Henan Province (grand no. 162102310404), the Fundamental Research Funds for the Henan Provincial Colleges and Universities in Henan University of Technology (grand no. 2015RCJH03).

\section{References}

1. Scorzoni L, de Lucas MP, Mesa-Arango AC, Fusco-Almeida AM, Lozano E, Cuenca-Estrella M, Mendes-Giannini MJ and Zaragoza O: Antifungal efficacy during Candida krusei infection in non-conventional models correlates with the yeast in vitro susceptibility profile. PLoS One 8: e60047, 2013.

2. Gedik H, Simșek F, Kantürk A, Yildirmak T, Arica D, Aydin D, Demirel $\mathrm{N}$ and Yokuş O: Bloodstream infections in patients with hematological malignancies: Which is more fatal-cancer or resistant pathogens? Ther Clin Risk Manag 10: 743-752, 2014.

3. Shorr AF, Gupta V, Sun X, Johannes RS, Spalding J and Tabak YP: Burden of early-onset candidemia: Analysis of culture-positive bloodstream infections from a large U.S. database. Crit Care Med 37: 2519-2526; quiz 2535, 2009.

4. Colombo AL, Tobón A, Restrepo A, Queiroz-Telles F and Nucci M: Epidemiology of endemic systemic fungal infections in Latin America. Med Mycol 49: 785-798, 2011.

5. Arendrup MC: Epidemiology of invasive candidiasis. Curr Opin Crit Care 16: 445-452, 2010.

6. Pemán J, Cantón E, Quindós G, Eraso E, Alcoba J, Guinea J, Merino P, Ruiz-Pérez-de-Pipaon MT, Pérez-del-Molino L, Linares-Sicilia MJ, et al: Epidemiology, species distribution and in vitro antifungal susceptibility of fungaemia in a Spanish multicentre prospective survey. J Antimicrob Chemother 67: 1181-1187, 2012.

7. Pushpanathan M, Rajendhran J, Jayashree S, Sundarakrishnan B, Jayachandran S and Gunasekaran P: Direct cell penetration of the antifungal peptide, MMGP1, in Candida albicans. J Pept Sci 18: 657-660, 2012.

8. Oliveira VK, Ruiz Lda S, Oliveira NA, Moreira D, Hahn RC, Melo AS, Nishikaku AS and Paula CR: Fungemia caused by Candida species in a children's public hospital in the city of São Paulo, Brazil: Study in the period 2007-2010. Rev Inst Med Trop Sao Paulo 56: 301-305, 2014.

9. Leroy O, Gangneux JP, Montravers P, Mira JP, Gouin F, Sollet JP, Carlet J, Reynes J, Rosenheim M, Regnier B, et al: Epidemiology, management, and risk factors for death of invasive Candida infections in critical care: A multicenter, prospective, observational study in France (2005-2006). Crit Care Med 37: 1612-1618, 2009. 
10. Bassetti M, Taramasso L, Nicco E, Molinari MP, Mussap M and Viscoli C: Epidemiology, species distribution, antifungal susceptibility and outcome of nosocomial candidemia in a tertiary care hospital in Italy. PLoS One 6: e24198, 2011.

11. Muñoz P, Sánchez-Somolinos M, Alcalá L, Rodríguez-Créixems M, Peláez T and Bouza E: Candida krusei fungaemia: Antifungal susceptibility and clinical presentation of an uncommon entity during 15 years in a single general hospital. J Antimicrob Chemother 55: 188-193, 2005.

12. Abbas J, Bodey GP, Hanna HA, Mardani M, Girgawy E, Abi-Said D, Whimbey E, Hachem R and Raad I: Candida krusei fungemia. An escalating serious infection in immunocompromised patients. Arch Intern Med 160: 2659-2664, 2000.

13. Huang J, Hao D, Chen Y, Xu Y, Tan J, Huang Y, Li F and Chen Y: Inhibitory effects and mechanisms of physiological conditions on the activity of enantiomeric forms of an $\alpha$-helical antibacterial peptide against bacteria. Peptides 32: 1488-1495, 2011.

14. Gopal R, Seo CH, Song PI and Park Y: Effect of repetitive lysine-tryptophan motifs on the bactericidal activity of antimicrobial peptides. Amino Acids 44: 645-660, 2013.

15. Lv Y, Wang J, Gao H, Wang Z, Dong N, Ma Q and Shan A: Antimicrobial properties and membrane-active mechanism of a potential $\alpha$-helical antimicrobial derived from cathelicidin PMAP-36. PLoS One 9: e86364, 2014.

16. Simon JP and Aunis D: Biochemistry of the chromogranin A protein family. Biochem J 262: 1-13, 1989.

17. Helman LJ, Ahn TG, Levine MA, Allison A, Cohen PS, Cooper MJ, Cohn DV and Israel MA: Molecular cloning and primary structure of human chromogranin A (secretory protein I) cDNA. J Biol Chem 263: 11559-11563, 1988.

18. Lugardon K, Raffner R, Goumon Y, Corti A, Delmas A, Bulet P, Aunis D and Metz-Boutigue MH: Antibacterial and antifungal activities of Vasostatin-1, the N-terminal fragment of chromogranin A. J Biol Chem 275: 10745-10753, 2000.

19. Lugardon K, Chasserot-Golaz S, Kieffer AE, Maget-Dana R, Nullans G, Kieffer B, Aunis D and Metz-Boutigue MH: Structural and biological characterization of chromofungin, the antifungal chromogranin A-(47-66)-derived peptides. J Biol Chem 276: 35875-35882, 2001.
20. Li RF, Lu YL, Lu YB, Zhang HR, Huang L, Yin Y, Zhang L, Liu S, Lu Z and Sun Y: Antiproliferative effect and characterization of a novel antifungal peptide derived from human chromogranin A. Exp Ther Med 10: 2289-2294, 2015.

21. Li RF, Yan XH, Lu YB, Lu YL, Zhang HR, Chen SH, Liu S and Lu ZF: Anti-candidal activity of a novel peptide derived from human chromogranin $\mathrm{A}$ and its mechanism of action against Candida krusei. Exp Ther Med 10: 1768-1776, 2015.

22. Roilides E, Lyman CA, Sein T, Gonzalez C and Walsh TJ: Antifungal activity of splenic, liver and pulmonary macrophages against Candida albicans and effects of macrophage colony-stimulating factor. Med Mycol 38: 161-168, 2000.

23. Petraitiene R, Petraitis V, Groll AH, Candelario M, Sein T, Bell A, Lyman CA, McMillian CL, Bacher J and Walsh TJ: Antifungal activity of LY303366, a novel echinocandin B, in experimental disseminated candidiasis in rabbits. Antimicrob Agents Chemother 43: 2148-2155, 1999.

24. Ebrahimzadeh Bideskan AR, Nikravesh MR, Hassanzadeh Taheri MM and Fazel AR: Lectin histochemical study of vasculogenesis during rat pituitary morphogenesis. Iran J Basic Med Sic 14: 161-169, 2011.

25. Ding Y, Tang J, Zou J, She R, Wang Y, Yue Z, Tian J, Xia K, Yin $J$ and Wang D: The effect of microgravity on tissue structure and function of rat testis. Braz J Med Biol Res 44: 1243-1250, 2011.

26. Prescott ML, Harley PJ and Klein AD: Microbiology. 5th edition. McGraw-Hill Companies, Inc., New York, NY, p949, 2002.

27. Pfaller MA and Diekema DJ: Epidemiology of invasive mycoses in North America. Crit Rev Microbiol 36: 1-53, 2010.

28. Kuang SY, Xiao WW, Feng L, Liu Y, Jiang J, Jiang WD, Hu K, Li SH, Tang L and Zhou XQ: Effects of graded levels of dietary methionine hydroxy analogue on immune response and antioxidant status of immune organs in juvenile Jian carp (Cyprinus carpio var. Jian). Fish Shellfish Immunol 32: 629-636, 2012.

29. Erdogan H, Fadillioğlu E, Kotuk M, Iraz M, Tasdemir S, Oztas Y and Yildirim Z: Effects of ginkgo biloba on plasma oxidant injury induced by bleomycin in rats. Toxicol Ind Health 22: 47-52, 2006. 